\title{
USES AND GRATIFICATION TAYANGAN DRAMA KOREA TERHADAP MAHASISWA KOMUNIKASI DAN PENYIARAN ISLAM UNIVERSITAS ISLAM AL-IHYA KUNINGAN
}

\author{
Andi Rahmad ${ }^{1}$ \\ Mia Nurislamiah ${ }^{2}$ \\ Anton Widodo ${ }^{3}$ \\ ${ }^{1,3}$ Institut Agama Islam Negeri Metro Lampung \\ ${ }^{2}$ Universitas Islam Al-Ihya Kuningan \\ E-mail : ${ }^{1}$ rendysalman@gmail.com, ${ }^{2}$ mia.elfauzi080214@gmail.com, \\ 3antonwidodo@metrouniv.ac.id,
}

\begin{abstract}
The purpose of study was conducted to determine the satisfaction motives sought and satisfaction fulfilled by students of Communication and Broadcasting of Islam Al-Ihya Kuningan Islamic University in watching Korean drama. This research is a qualitative descriptive study using an interactive model. And data collection in this study was obtained through triangulation methods. While the data validity test is checked using source triangulation techniques. The results of this study indicate that: 1) Gratification sought (motive) of Islamic Communication and Broadcasting students at Al-Ihya Kuningan Islamic University is as entertainment, where with entertainment can reduce the tension of the mind and make the mind fresh again. 2) Gratification obtained (satisfaction) of Islamic Communication and Broadcasting Al-Ihya Kuningan Islamic University students is greater than the desired satisfaction, so that viewers can feel satisfied after watching Korean drama shows.
\end{abstract}

Keywords: Uses and Gratification, Students, Korean Drama

\begin{abstract}
Abstrak
Tujuan penelitian ini dilakukan untuk mengetahui motif kepuasan yang dicari dan kepuasan yang diajukan oleh mahasiswa Komunikasi dan Penyiaran Universitas Islam Al-Ihya Kuningan Islam dalam menonton drama Korea. Penelitian ini adalah penelitian deskriptif kualitatif dengan menggunakan model interaktif. Dan mengumpulkan data dalam penelitian ini diperoleh melalui metode triangulasi. Sedangkan uji validitas data menggunakan teknik triangulasi sumber. Hasil penelitian ini menunjukkan bahwa: 1) Gratifikasi yang dicari (motif) mahasiswa Komunikasi Islam dan Penyiaran di Universitas Islam Al-Ihya Kuningan adalah sebagai sarana hiburan, di mana dengan hiburan dapat melepaskan pikiran dan membuat pikiran kembali. 2) Gratifikasi yang diperoleh (kepuasan) mahasiswa Komunikasi Islam dan Penyiaran mahasiswa Universitas Islam Al-Ihya Kuningan lebih besar dari kepuasan yang dibutuhkan, sehingga pemirsa dapat puas setelah menonton drama Korea.
\end{abstract}

Keywords: Uses and Gratification, Mahasiswa, Drama korea 


\section{PENDAHULUAN}

Dewasa ini, Korea menjadi salah satu eksportir program televisi yang sukses, tidak hanya di kawasan Asia bahkan kesuksesan tersebut telah mencapai benua Eropa dan Amerika. Saat ini, Korea dapat dikatakan berhasil menjadi saingan berat Hollywood dan Bollywood dalam melebarkan sayap budayanya ke dunia internasional melalui tayangan hiburan seperti film, drama dan musik yang bernuansa Asia. Kemajuan yang dialami Korea dalam bidang hiburan tidak melupakan jati dirinya namun tetap mengemas nilai-nilai Asia di dalam industri hiburan. Hal inilah yang menjadi daya tarik tersendiri, terutama bagi masyarakat Asia yang merasa ada kedekatan tersendiri saat menyaksikannya.

Film berperan sebagai sarana baru yang digunakan untuk menyebarkan hiburan yang sudah menjadi kebiasaan terdahulu, serta manyajikan cerita, peristiwa, musik, drama, lawak dan sajian teknis lainnya kepada masyarakat. Film mampu merangsang dua indera sekaligus yaitu indera penglihatan dan pendengaran, sehingga dapat memberikan pengaruh yang besar kepada audiensnya. Film memiliki kemampuan untuk menarik perhatian orang dan sebagian lagi didasari oleh alasan bahwa film memiliki kemampuan mengantar pesan secara unik. ${ }^{1}$ Film adalah potret dari masyarakat di mana film itu dibuat. Film selalu merekam realitas yang tumbuh dan berkembang dalam masyarakat, dan kemudian memprovokasikannya ke atas layar. Salah satu genre film yang memotret kehidupan masyarakat adalah film drama. ${ }^{2}$

Drama biasanya berhubungan dengan tema, cerita, setting, karakter serta suasananya yang memotret kehidupan nyata. Kisahnya sering kali menggugah emosi, dramatik, dan mampu menguras air mata penontonnya. Tema umumnya mengangkat ema sosial baik skala besar (masyarakat) maupun skala kecil (keluarga). ${ }^{3}$ Drama merupakan tiruan kehidupan manusia yang diproyeksikan di atas pentas. Drama adalah potret kehidupan manusia, potret suka duka, pahit manis dan hitam putih kehidupan manusia. ${ }^{4}$

1 Handi and Oktavianus, "Praktek Eksorsis Di Dalam Film Conjuring", E-Komunikasi, (2015), hal. $1-12$.

2 Muhammad Taufiq Hidayat, "Computers in Human Behavior", UPT Perpustakaan ISI Yogyakarta, (2019), (https://doi.org/10.1016/j.chb.2016.05.008).

3 H Burkhardt and others, "Representasi Penyandang Disabilitas Dalam Film (Analisis Semiotika Barthes Dalam Film Serial Animasi "Nussa Dan Rara")", Society, 2019

(https://doi.org/10.1017/CB09781107415324.004).

${ }^{4}$ Indotesis.com, "Pengertian, Jenis dan Unsur Drama" https://medium.com/@indotesis/pengertian-jenis-dan-unsur-drama-1d69c088bcab)

Vol. 3, No. 1, Juni 2020, pp 1-16

Andi, Mia \& Anton

Uses And Gratification Tayangan Drama... 
Korea merupakan Negara yang terkenal dengan keseniannya, seperti K-Pop, Boy band dan Girls band atau bahkan drama yang mereka suguhkan. Dari kesenian inilah mereka mulai menjadi figur yang tidak dapat tampil apa adanya, karena penampilan memberi kesan tersendiri bagi masyarakat. Fashion merupakan salah satu daya tarik yang membuat mereka tampil menarik. Tampilan fashion yang sederhana namun tetap terlihat elegan merupakan gaya fashion Korea. Namun berbeda dengan gaya berbusana pada Boy band ataupun Girls band yang terbuka, fashion yang disuguhkan pada drama Korea lebih tertutup.

Selain itu, Keindahan dan budaya yang dimiliki oleh Negara Korea, juga merupakan salah satu daya tarik yang dimanfaatkan, untuk mengenalkannya ke seluruh dunia melalui drama yang mereka buat. Hal inilah yang menyebabkan Hallyu (Gelombang Korea) yakni meningkatnya minat publik pada kesenian pop dan tradisional Korea di Asia, Eropa, Timur Tengah, dan benua Amerika. ${ }^{5}$ Indonesia juga telah mengalami Hallyu ini sejak kemunculannya brama Korea.

Drama Korea merupakan program televisi drama yang berisi tentang kisah kehidupan di Korea yang kemudian diproyeksikan menjadi sebuah drama film. Pada tahun 2020 terdapat drama Korea yang fenomenal dengan judul Crash Landing on You, Itaewon Class, Hot Stove League, Tell Me What You Saw, Beautiful Love, Wonderful Life, Selection: The War Between Woman (drama ini menceritakan tentang romansa di dalam sebuah istana juga diselipi drama meraih kekuasaan). ${ }^{6}$ Dibandingkan dengan drama-drama lain, drama Korea selalu menyuguhkan cerita dengan alur cerita yang lebih simple dan ringan serta tidak berbelit-belit, episode yang disuguhkan oleh drama Korea lebih pendek antara 16 episode hingga 30 episode. Selain itu, latar tempat yang dimunculkan di setiap adegan juga lebih bervariasi. Berbeda dengan drama luar lain seperti drama India yang menitikberatkan cerita pada satu masalah namun bercabang menjadi beberapa masalah, episode yang ditayangkan juga lebih banyak sehingga menimbulkan rasa bosan.

Drama Korea terkenal dengan gaya fashionnya yang elegan. Karena hal inilah, fashion Korea mulai digandrungi para mahasiswa/remaja dan menjadi trend. Namun, hal ini menyebabkan individu meniru gaya berbusana ataupun fashion yang

5 Kedutaan Besar Republik Korea untuk Republik Indonesia, "Hallyu: Gelombang Korea (Korea Wave)", (2020), (http://overseas.mofa.go.kr/id-id/wpge/m_2741/contents.do).

6 Rintan Puspita and Pangerang, "10 Drama Korea Terbaru Tayang Maret 2020, Yang Mana Paling Dinantikan?", (2020), (https://www.kompas.com/hype/read/2020/02/28/154714766/10drama-korea-terbaru-tayang-maret-2020-yang-mana-paling-dinantikan?page=all).

Vol. 3, No. 1, Juni 2020, pp 1-16

Andi, Mia \& Anton

Uses And Gratification Tayangan Drama... 
ditampilkan oleh pemain drama Korea. Selain itu, sifat mahasiswa yang selalu mengikuti trend terbaru juga mempengaruhi teman mereka. Sikap ini menimbulkan perilaku konsumtif bagi mahasiswa, mereka akan menghabiskan uang untuk membeli pakaian ataupun aksesoris yang mereka inginkan, sehingga mereka menjadi bersikap boros. ${ }^{7}$ Dimana sikap boros itu merupakan sikap yang kurang baik, hal ini dapat dijelaskan dalam AI-Qur"an surat AI-Israa" ayat 26-27:

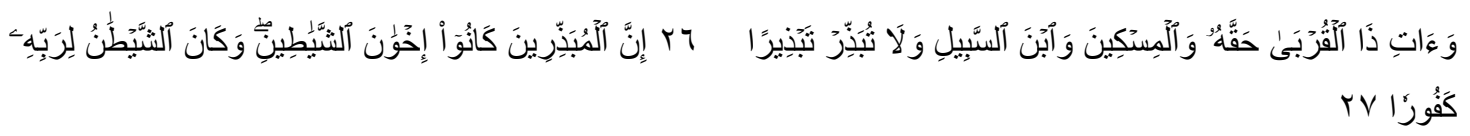

Artinya: Dan berikanlah kepada keluarga-keluarga yang dekat akan haknya, kepada orang miskin dan orang yang dalam perjalanan dan janganlah kamu menghambur-hamburkan (hartamu) secara boros. Sesungguhnya pemborosanpemborosan itu adalah saudara-saudara syaitan dan syaitan itu adalah sangat ingkar kepada Tuhannya. ${ }^{8}$

Di dalam surat tersebut dijelaskan bahwa Allah SWT telah melarang sikap boros. Sikap boros akan merugikan orang yang melakukan pemborosan seperti mahasiswa, dimana sebagian besar mahasiswa belum berpenghasilan sendiri dan masih meminta uang saku pada orang tua mereka. Selain itu, drama Korea tidak pernah lepas dengan genre romantis. Genre romantis tentunya di dominasi dengan adegan mesra antara dua orang individu yang berlawanan jenis. Dengan terpaan yang terus menerus menyebabkan individu terpengaruh, sehingga menimbulkan keinginan pada individu untuk dapat meniru adegan tersebut. Di dalam agama islam adegan mesra merupakan salah satu larangan karena dapat menimbulkan zina sehingga dapat merusak moral.

Dalam Al-Qur"an dijelaskan pada surat Al-Isra" ayat 32:

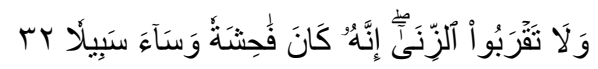

Artinya: "Dan janganlah kamu mendekati zina, sesungguhnya zina itu adalah perbuatan yang keji dan jalan yang buruk.",

\footnotetext{
7 Yunita Wulan Sari, "Dampak Tayangan Drama Korea "Fashion King" Di Indosiar Pada Perilaku Konsumtif Remaja Putri Di Desa Karya Jaya", (2014), (https://www.printfriendly.com/p/g/L4Z4Ht).

8 Qur'an Kemenag, "Qur'an Kemenag", Lajnah Pentashihan Mushaf Al-Qur'an, (2020).

9 Qur'an Kemenag.
}

Vol. 3, No. 1, Juni 2020, pp 1-16 
Dapat dijelaskan bahwa mendekati zina di larang dalam agama islam. Kegiatan pacaran dapat menyebabkan perbuatan zina. Jika itu terjadi, hal ini akan merusak moral mahasiswa itu sendiri dan akan mengakibatkan perasaan bersalah dikemudian hari. Dalam teori uses and gratification dijelaskan bahwa penonton akan menjadi aktif dan selektif dalam memilih tayangan yang mereka inginkan. Setiap individu memiliki motif dan tingkat kepuasan yang berbeda-beda. Hal ini yang menimbulkan teori uses and gratification. Menurut pendiri teori ini, Blumer dan Katz, mengatakan pengguna media memainkan peran aktif untuk memilih dan menggunakan media tersebut. Pengguna mempunyai pilihan alternatif untuk memuaskan kebutuhan mereka. ${ }^{10}$

Media massa tidak mempunyai kekuatan mempengaruhi khalayak. Khalayak pada dasarnya menggunakan media massa berdasarkan motif-motif tertentu. Media dianggap berusaha memenuhi motif khalayak. Jika ini terpenuhi maka kebutuhan khalayak akan terpenuhi. ${ }^{11}$ Banyaknya drama luar yang tayang di Indonesia, tentunya memiliki daya tarik yang berbeda-beda. Isi media yang sampai kepada individu, akan menentukan individu untuk tetap melihat atau tidak tayangan tersebut. Tayangan yang lebih menarik untuk dilihat pada akhirnya akan membuat individu bertahan untuk menonton tayangan tersebut hingga akhir. Namun, sebaliknya, jika tayangan tersebut tidak menarik, maka penonton juga akan berhenti dan memilih tayangan lain yang lebih menarik. Penonton juga akan berusaha mendapatkan tayangan yang mereka inginkan salah satunya dengan mencarinya di internet.

Kemudahan akses internet, memudahkan individu mencari dan mendownload apa saja yang mereka butuhkan. Kemudahan ini dimanfaatkan penggemar drama Korea untuk mendapatkan drama terupdate. Tanpa menunggu lama, mereka dapat membuka laman download dan mendapatkan semua judul drama yang diinginkan. Beberapa laman download drama Korea antara lain; drakorindo.com, kdramaindo.com, drakortv.com, dramaKorea.web .id. Berdasarkan uraian tersebut, peneliti berpendapat bahwa audiens pengguna media akan secara aktif mencari informasi, hiburan dan lainnya di dalam media massa berdasarkan kehendak atau kebutuhan, dan motif yang mereka miliki. Motif setiap audiens tentunya beragam dalam menggunakan media. Selanjutnya, setelah kebutuhan yang mereka cari terpenuhi maka akan menimbulkan tingkat kepuasan pada audiens yang berbeda-beda.

10 Yusuf Sapari, "Komunikasi Dalam Perspektif Teori Pertukaran", Jurnal Signal, (2018), (https://doi.org/10.33603/signal.v6i1.950).

11 Dewi Widoawati, "Efek Media Massa Terhadap Khalayak", Jurnal Adzikra, (2012), (https://doi.org/10.1017/CB09781107415324.004).

Vol. 3, No. 1, Juni 2020, pp 1-16 


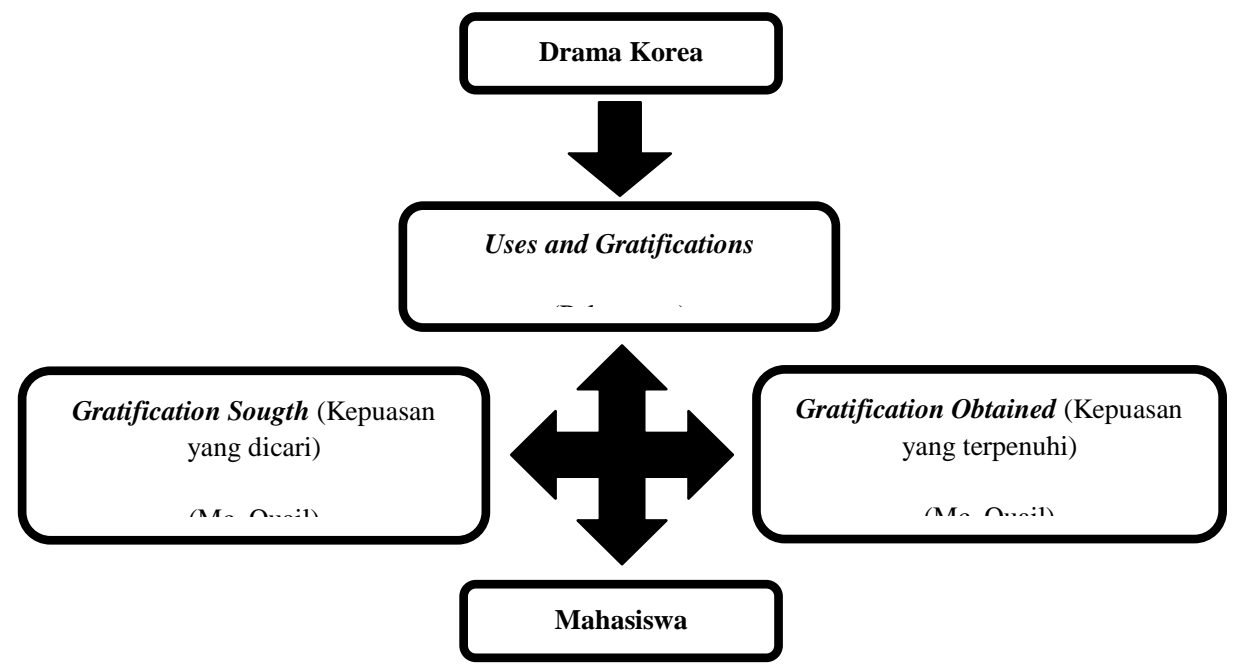

Gambar 1. Teori Uses and Gratification

Berdasarkan tabel diatas bahwa teori uses and gratification menurut Palmgreen. Individu yang menggunakan media memiliki motif dan kepuasan. Dimana seseorang sebelum menonton drama Korea memiliki motif untuk memenuhi kebutuhan mereka, kemudian setelah seseorang menonton akan timbul kepuasan yang didapat dari menonton itu tersebut. Sehingga dari motif dan kepuasan tersebut akan timbul kesenjangan. Kesenjangan kepuasan ini tidak akan terjadi manakala kebutuhan yang diinginkan terpenuhi. Dalam hal ini media massa menjalankan perannya dengan sangat baik, sehingga menimbulkan perasaan puas dan bahagia karena apa yang media massa berikan telah memenuhi semua kebutuhan. Disisi lain, kesenjangan kepuasan ini pun akan muncul apabila media massa terlalu banyak memberikan apa yang dibutuhkan dibandingkan dengan kebutuhan yang diinginkan.

Penelitian ini merupakan penelitian deskriptif kualitatif. Penelitian deskriptif adalah penelitian yang dilakukan untuk menggambarkan dan melukiskan keadaan obyek penelitian pada saat sekarang sebagaimana adanya berdasarkan fakta-fakta. Penelitian ini merupakan usaha untuk mengungkapkan masalah atau keadaan atau peristiwa sebagaimana adanya sehingga hanya mendeskripsikan fakta. Hasil penelitian ditekankan untuk memberi gambaran secara obyektif tentang keadaan yang sebenarnya dari subyek yang diteliti.

Penelitian ini dilakukan dengan menggunakan model interaktif yang dikemukakan oleh Saldana bahwa sktivitas dalam analisis data kualitatif dilakukan secara interaktif dan berlangsung secara terus menerus sampai tuntas, sehingga

Vol. 3, No. 1, Juni 2020, pp 1-16 
datanya jenuh. Aktivitas dalam analisis terdiri dari kondensasi data (data condensation), penyajian data (data display), serta penarikan kesimpulan dan verivikasi (conclusion drawing/verification). ${ }^{12}$ Tujuan dilaksanakannya penelitian deskriptif kualitatif ini adalah untuk memberikan gambaran secara sistematis, faktual dan akurat tentang suatu fakta tertentu tentang motif dan kepuasan mahasiswa Komunikasi dan Penyiaran Islam Universitas Islam Al-Ihya Kuningan dalam menonton drama Korea.

Peneliti berfokus pada penentuan partisipan dalam kelompok yang bertujuan untuk memperoleh partisipan yang bersifat homogen. ${ }^{13}$ Partisipan dalam penelitian ini berjumlah 4 orang terdiri dari 2 orang mahasiswa tingkat II dan 2 orang mahasiswa KPI tingkat IV. Pengumpulan data dalam penelitian ini diperoleh melalui triangulasi metode, yaitu: observasi dan studi dokumen pada tahap studi pendahuluan, dan wawancara. Peneliti juga melakukan triangulasi data dengan sumber melalui perbandingan dan pengecekan ulang derajat kepercayaan sebuah informasi yang diperoleh pada waktu dan alat yang berbeda.

\section{PEMBAHASAN}

Teori penggunaan dan kepuasan memfokuskan perhatian pada audiens sebagai konsumen media massa, dan bukan pada pesan yang disampaikan. Teori ini menilai bahwa audiens dalam menggunakan media berorientasi pada tujuan, bersifat aktif sekaligus diskriminatif. Audiens dinilai mengetahui kebutuhan mereka dan mengetahui serta bertanggung jawab terhadap pilihan media yang dapat memenuhi kebutuhan mereka tersebut. Teori penggunaan dan kepuasan menjelaskan mengenai kapan dan bagaimana audiens sebagai konsumen media menjadi lebih aktif atau kurang aktif dalam menggunakan media dan akibat atau konsekuensi dari penggunaan media itu. Penggunaan media didorong oleh adanya kebutuhan dan tujuan yang ditentukan oleh audiens sendiri. ${ }^{14}$

Katz, Blumler dan Gurevitch, menyatakan lima asumsi dasar teori penggunaan dan kepuasan yaitu: 1) audiensi aktif dan berorientasi pada tujuan ketika

\footnotetext{
12 Paluseri, "Kondensasi Dalam Analisis Data Penelitian Kualitatif", (2019) (https://kacamatapustaka.wordpress.com/2019/11/08/kondensasi-dalam-analisis-datapenelitian-kualitatif-2/).

13 Suyitno, "Penelitian Kualitatif", Journal Equilibrium, 5 No. 9.C (2009), (yusuf.staff.ub.ac.id/files/2012/11/Jurnal-Penelitian-Kualitatif.pdf).

14 Wikipedia, "Teori Penggunaan dan Pemenuhan Kepuasan", (2019) (https://id.wikipedia.org/wiki/Teori_penggunaan_dan_pemenuhan_kepuasan).
}

Vol. 3, No. 1, Juni 2020, pp 1-16

Andi, Mia \& Anton

Uses And Gratification Tayangan Drama... 
menggunakan media; 2) inisiatif untuk mendapatkan kepuasan media ditentukan audiensi; 3) media bersaing dengan sumber kepuasan lain; 4) audiensi sadar sepenuhnya terhadap ketertarikan, motif, dan penggunaan media; dan 5) penilaian isi media ditentukan oleh audiensi. ${ }^{15}$ Audiensi memiliki sejumlah alasan dan berusaha mencapai tujuan tertentu ketika menggunakan media. McQuail dan rekan mengemukaan empat alasan mengapa audiensi menggunakan media, yaitu : ${ }^{16}$

a. Pengalihan (disversion), yaitu melarikan diri dari rutinitas atau masalah sehari-hari.

b. Hubungan personal; hal ini terjadi ketika orang menggunakan media sebagai pengganti teman.

c. Identitas personal, sebagai cara memperkuat nilai-nilai individu.

d. Pengawasan (surveillance), yaitu informasi mengenai bagaimana media membantu individu mencapai sesuatu.

Dari penjelasan di atas, bahwa teori uses and gratification ini menjelaskan tentang sifat audiens yang aktif dalam mengkonsumsi media sehingga mereka dapat selektif dalam memilah milah pesan media yang bertujuan untuk memenuhi kebutuhan audiensi. Pemilihan media yang dilakukan oleh audiensi merupakan salah satu cara pemenuhan kebutuhan mereka dalam menerima informasi. Mereka dapat memilih media yang mana yang akan mereka konsumsi sehingga motif ataupun kepuasaan akan mereka dapatkan sesuai apa yang mereka inginkan.Menurut riset uses and gratification di atas, peneliti berpendapat bahwa motif individu dalam menggunakan media sangat berpengaruh dalam memenuhi kepuasan individu akan kebutuhan individu tersebut. Dalam penelitian ini ditujukan untuk mengetahui motif dan kepuasan mahasiswa Komunikasi dan Penyiaran Islam Universitas Islam Al-Ihya Kuningan dalam menonton Drama Korea.

\section{Gratification Sought (Motif)}

Gratification Sought adalah kepuasan yang dicari atau diinginkan pengguna ketika menggunakan suatu jenis media tertentu. Dengan kata lain, pengguna akan memilih atau tidak memilih suatu media tertentu dipengaruhi oleh sebab-sebab tertentu, yaitu didasari motif pemenuhan sejumlah kebutuhan yang ingin dipenuhi. ${ }^{17}$

\footnotetext{
15 Ismed Nompo, "Uses and Gratification Theory", (2016)

(https://www.kompasiana.com/ismednompo/58154bb5579773b5621e253b/uses-andgratification-theory?page=all).

16 Dea Anggraeni Utomo, "Motif Pengguna Jejaring Sosial Google + Di Indonesia", E-Komunikasi, 1.2 (2013).

17 Rachmat Kriyantono, "Teknik Praktis Riset Komunikasi", Google Books, Kencana Prenada Media Group, 2006) hal. 213.
}

Vol. 3, No. 1, Juni 2020, pp 1-16

Andi, Mia \& Anton

Uses And Gratification Tayangan Drama... 
Dengan menonton cerita dalam drama Korea, mahasiswa mendapatkan hiburan di waktu luangnya. Motif ini berhubungan dengan keinginan bersantai, menyalurkan emosi dan melupakan permasalahan yang dihadapi. Motif utama responden dalam menonton drama Korea adalah ingin bersantai.

Hasil ini menunjukkan bahwa sebagian besar mahasiswa memang benarbenar hanya mencari hiburan ketika menonton drama Korea. Dengan kata lain, latar belakang mahasiswa menonton drama Korea adalah mahasiswa yang memiliki kebiasaan dan kesenangan yang berhubungan dengan aktivitas menonton drama, mereka memiliki lebih banyak waktu luang dan ingin mengisinya dengan kegiatan yang menyenangkan, bisa dilakukan bersama-sama, dan mengikuti perkembangan terbaru dengan menonton drama Korea yang ditayangkan baik melalui media online maupun media televisi. Bahwa dengan motif hiburan (diversion) ini dapat menyalurkan emosi seseorang sebagai salah satu cara aktualisasi diri dan memberikan kesenangan kepada diri sendiri.

Motif hiburan (diversion) selanjutnya adalah agar dapat melupakan permasalahan yang sedang dihadapi, setelah melewati berbagai ketegangan dalam menjalani hari, baik itu berhubungan dengan kuliah dan aktifitas lainnya, responden memilih untuk melupakan permasalahan-permasalahan yang ada dengan mengalihkan perhatiannya melalui drama Korea. Secara keseluruhan, melalui menonton drama Korea, mahasiswa ingin mendapatkan hiburan yang menyenangkan dengan menonton drama Korea. Temuan penelitian mengenai motif hiburan (diversion) menurut McQuail, Blumber, dan Brown (1972) yang menyatakan bahwa salah satu motif menonton drama adalah motif yang meliputi kebutuhan atau pelepasan diri dari tekanan dan kebutuhan akan hiburan. Motif ini berhubungan dengan keinginan untuk bersantai, ingin melepaskan diri dari permasalahan, mengisi waktu luang, mengatasi rasa bosan dan menikmati kenikmatan jiwa estetis. ${ }^{18}$ Sebagian mahasiswa merasa setelah menonton dan sebelum menonton drama korea merasa bahwa setiap tekanan dan beban yang dirasakahn akan sedikit berkurang dan terlupakan. Semacam di reset kembali perasaan dan pikiran penonton, itulah yang membuat penonton merasa lega dan lepas beban setelah menonton drama korea.

\footnotetext{
18 Deshinta Firstiiana Sari, "Motif Menonton Drama Korea Di Televisi Oleh Remaja Surabaya", Commonline Departement Komunikasi, (2015), (http://journal.unair.ac.id/downloadfullpapers-comme465029b70full.pdf.).
}

Vol. 3, No. 1, Juni 2020, pp 1-16 


\section{Gratification Obtained (Kepuasan)}

Gratification Obtained adalah sejumlah kepuasan nyata yang diperoleh individu atas terpenuhinya kebutuhan-kebutuhan tertentu setelah individu tersebut menggunakan media. ${ }^{19}$ Seperti kebutuhan untuk bersenang-senang dan merasa bahagia hanya dengan melihat suatu tayangan ataupun drama. Kebutuhan yang dapat merefleksikan keinginan dalam bentuk dan cara yang lain. Dengan menonton drama korea dapat membantu meregangkan pikiran yang stress akibat tugas kuliah serta tugas-tugas lainnya yang sedang dirasakan. Kepuasan yang diperoleh mahasiswa dalam menonton drama Korea, diantaranya :

a. Kepuasan informasi, mahasiswa dikatakan mendapatkan kepuasan informasi apabila :

1. Dapat mengetahui berbagai peristiwa dan kondisi yang berkaitan dengan lingkungan masyarakat terdekat. Kaitannya dengan drama Korea, mahasiswa dapat dengan mudah mendapatkan informasi seputar tradisi khas Korea, kebiasaan actor atau aktris drama, dan seputar apa yang sedang tren (seperti fashion and food) di negeri ginseng tersebut.seperti yang sedang tren saat ini adalah bagaimana fashion korea dapat mempengaruhi tren fashion dunia, khususnya di Indonesia. Bagaimana mahasiswa Universitas Islam Al-Ihya banyak mengadopsi tren fhashion korea, juga makanan-makanan yang banyak disukai mahasiswa. Ditambah dengan tren-tren lainnya yang sedang hits di korea.

2. Dapat mengetahui berbagai informasi mengenai peristiwa dan kondisi yang berkaitan dengan keadaan dunia. Dalam drama Korea tersebut seringkali menunjukan scene yang menggambarkan tentang issue yang terkini seputar politik dunia, ataupun seputar bisnis yang secara global diperlihatkan. Misalnya seperti film Flu yang ditayangkan beberapa tahun silam. Dalam film tersebut menggambarkan bagaimana situasi salah satu kota yang menjadi gaduh akibat pandemic yang sedang dialami. Sector ekonomi, perhubungan, dan pertahanan menjadi imbas dari pandemic yang melanda kota tersebut.

3. Dapat mencari bimbingan menyangkut berbagai masalah. Dalam drama Korea juga banyak pepatah cina atau konfusius yang dipakai untuk menyelesaikan permasalahan. Seperti terdapat dalam scene drama Korea yang berjudul

19 Rachmat Kriyantono, "Teknik Praktis Riset Komunikasi", Google Books', Kencana Prenada Media Group, (2006) hal. 215 
Moonlight Drawn By Clouds pada episode ke 7 menurut Joo Yuk "(kitab perubahan) meskipun membuat usaha berat secara mental dan fisik, kita masih harus beristirahat ketika hari sudah gelap", dan menurut Seo Gyeong yang menyatakan bahwa "(kitab kepustakaan) meskipun anda tersadar dari kemalasan anda boleh bermalas-malasan hanya jika anda tau apa itu kesulitan".

4. Dapat mencari bimbingan menyangkut berbagai pendapat. Secara tidak langsung saat seseorang menonton suatu tayangan film atau drama akan banyak memperoleh bimbingan secara tidak langsung terkait dengan bagaimana cara menyampaikan pendapat pribadi melalui scene dalam drama tersebut.

5. Dapat memperoleh rasa damai melalui penambahan pengetahuan. Mahasiswa merasa senang dapat menegtahui pengetahuan yang baru tanpa bersusah payah meneliti gejala-gejala yang terjadi di lingkungan sosialnya.

b. Kepuasan identitas pribadi, mahasiswa dikatakan mendapatkan kepuasan identitas pribadi apabila :

1. Dapat menemukan penunjang nilai-nilai yang berkaitan dengan pribadi mahasiswa itu sendiri;

2. Dapat mengidentifikasikan diri dengan nilai-nilai lain dalam media;

3. Memperoleh nilai lebih sebagai mahasiswa.

c. Kepuasan integrasi dan interaksi social, mahasiswa dikatakan mendapatkan kepuasaan integrassi dan interaksi sosial apabila :

1. Memperoleh pengetahuan yang berkenaan dengan empati social;

2. Dapat menemukan bahan percakapan dan interaksi social dengan orang lain disekitarnya;

3. Dapat menjalankan peran sosial sebagai mahasiswa;

4. Keinginan dekat dengan orang lain;

5. Keinginan untuk dihargai orang lain.

d. Kepuasan hiburan, mahasiswa dikatakan mendapatkan kepuasan hiburan apabila :

1. Dapat melepaskan diri dari permasalahan;

2. Bisa bersantai dan mengisi waktu luang;

3. Bisa menyalurkan emosi;

4. Bisa mendapatkan hiburan dan kesenangan.

Bukan hal yang mudah bagi seseorang untuk mendapatkan pengalaman serta pelajaran dari setiap tayangan yang ditampilkan dalam televise ataupun media social. Namun, dalam tayangan drama korea ini dengan sangat mudah dipahami dan dimgerti 
setiap gejala ataupun peristiwa yang menyangkut pada perasaan ataupun kehidupan pribadi pada masing masing orangnya. Mahasiswa Islam Al-lhya menutukan bahwa tidak sepenuhnya pelajaran didapatkan dalam menonton drama korea, melainkan setidaknya lebih memberikan kemudahan dalam menggambarkan setiap gejala yang terjadi di lingkungan social dengan bentuk drama/tayangan. Mahasiswa Islam Al-Ihya menuturkan bahwa meskipun drama korea seluruhnya menjelaskan tentang sikap dan gejala-gejala nonislami, tapi mahasiswa Islam Al-Ihya dapat memfilter tayangan tersebut sehingga tetap tidak membuat mahasiswa melakukan kewajibannya sebagai seorang muslimah dan sebagai seorang mahasiswa di suatu perguruan tinggi.

Menurut Palmgreen gratification obtained mempertanyakan hal-hal yang khusus mengenai apa saja yang diperoleh setelah menggunakan media dengan menyebutkan acara atau rubrik tertentu secara spesifik. Seperti tentang bagaimana kita merasa bahagia, terhibur dan merasa tenang dengan alur cerita dalam drama. Seperti dalam menonton drama korea, yang terkadang judul drama nya seperti biasabiasa saja malah terkesan membosankan ternyata setelah menonton langsung drama tersebut malah memberikan dampak yang sangat besar. Beberapa orang dalam hasil wawancara mengatakan bahwa, dengan menonton drama korea dapat membuat penonton lebih mengerti dan memahami keadaan yang sebelumnya belum pernah dialami dan dirasakan. Ditambah dengan dapat merasakannya situasi seperti keadaan social ataupun emosional seperti dalam cerita drama korea. Menariknya, drama korea berbeda dengan drama-drama yang ada di beberapa Negara.

Dari mulai setting cerita, alurnya, kemudian karakter dan lainnya itu sangan mendukung pada penguatan cerita nya. Seperti menurut salah satu aktris dalam drama World Of The Married mengatakan bahwa setiap adegan itu didukung dengan narasi yang luar biasa. Soundtrack yang mengiringi pun sangat sesuai dengan setiap alur yang ditampilkan. Penguatan cerita dan karakter dalam sebuah drama tidak hanya dengan narasi, actor aktris, alur cerita dan soundtrack saja, melainkan dengan penguatan dan penegasan dalam audio. Sutradara dalam drama korea World Of The Married menjelasakan bahwa setiap adegannya selalu diiringi dengan audio pendukung, seperti dalam adegan cemas dan gelisah, maka akan diiringi dengan audio yang tak kalah mendebarkan dan membuat penonton menjadi ikut gelisah dan cemas. Begitupun dengan rasa takut dan kaget, maka penonton pun akan sama merasakan takut dan kaget seperti dalam cerita. 
Drama korea mampu membuat penonton menjadi ikut merasakan setiap detail yang ada dalam alur cerita. Setiap episode akan menampilkan seluruh adegan dengan narasi yang tidak dapat ditebak plot nya berarah kemana. Setiap adegan selalu kuat dengan audio, lighting dan karakter yang menjadi sangat kuat dan jelas dalam setiap cerita nya. Itulah mengapa drama korea selalu sukses berjajar dengan drama-drama dari Negara lain. Motif yang dapat meningkatkan nilai kepuasan adalah motif integrasi dan interaksi sosial. Hal ini sesuai dengan fungsi komunikasi massa yakni surveillance atau pengawasan instrumental yakni menyampaikan atau menyebarkan informasi yang memiliki kegunaan atau dapat membantu khalayak dalam kehidupan sehari-hari. Sehingga penonton dapat memiliki bahan obrolan dengan teman mereka atau hanya sekedar menambah informasi bagi dirinya sendiri.

Drama korea selalu memberikan cerita yang bervariatif. Dari mulai cerita tentang duka yang kemudian dikemas sedemikian rupa berikut solusi-solusi yang yang seperti cerita nyata terjadi. Sehingga dapat membuat penonton merasa terhibur dan terefleksikan. Kemudian drama korea pun menampilkan cerita-cerita yang ringan dan menggelitik seperti genre romcom istilah nya komedi romantic. Pada genre ini dijelaskan mempunyai cerita yang ringan untuk dipahami dan dimengerti, serta diberikan berbagai narasi komedi yang dapat menambah rasa bahagia dan membuat cerita dan alurnya semakin menarik.

Seperti drama korea yang berjudul Touch Your heart yang menampilkan cerita tentang seorang aktris yang mempunyai skandal dengan kehidupannya dan berakhir dengan bekerja di sebuat Firma Hukum di Korea. Alur dan cerita dalam drama ini sangat menyenangkan dan tidak terlalu banyak konflik. Serta soundtrack yang sangat sesuai dengan cerita yang ditampilkan. Hanya saja dalam drama korea yang bergenre horror ataupun laga, cerita nya akan sangat lebih apik dan dramatis.

Begitu banyaknya genre dan pilihan cerita dalam drama korea membuat penonton menjadi semakin ketagihan. Dan jarang sekali ada yang merasa puas hanya dengan satu genre cerita saja. Namun ada juga sebagian penonton yang tidak hanya menonton drama korea saja, melainkan menonton beberapa program talkshow ataupun variety show, tergantung pada kebutuhan apa saja yang dibutuhkan oleh penonton. Dari penjelasan tersebut dapat peneliti simpulkan bahwa penonton memiliki kebutuhan atau tujuan sendiri dalam menggunakan media, hal ini berkaitan dengan karakter penonton berdasarkan tipologi formasi audiens tipe kedua atau kelompok kepuasan yang menjelaskan bahwa audiens mengkonsumsi media didasarkan pada 
kebutuhan dan tujuan tertentu. Selain itu, sebagian besar responden menggunakan media untuk memenuhi kebutuhan hiburan, hal ini sesuai dengan fungsi komunikasi massa yaitu hiburan. Dimana hiburan dapat mengurangi ketegangan pikiran dan membuat pikiran segar kembali.

Hal ini sesuai dengan fungsi komunikasi massa yakni pengawasan instrumental yakni menyampaikan atau menyebarkan informasi yang memiliki kegunaan atau dapat membantu khalayak dalam kehidupan sehari-hari. Sehingga penonton dapat memiliki bahan pembicaraan baru dengan teman-teman mereka. Mereka dapat berbicara apa adanya tanpa mengada-ada sesuai fakta. Sebagaimana dijelaskan dalam surat al-Isra" ayat 36:

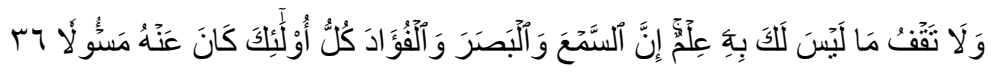

Artinya: "Dan janganlah kamu mengikuti apa yang kamu tidak mempunyai pengetahuan tentangnya. Sesungguhnya pendengaran, penglihatan dan hati, semuanya itu akan diminta pertanggungan jawabnya." 20

Ayat diatas menjelaskan bahwa setiap apa yang kita dengar dan kita lihat akan dipertanggungjawabkan di akhirat nanti. Dari ayat tersebut kita dapat mengambil pelajaran bahwa pendengaran dan penglihatan yang tidak benar saja dapat menimbulkan masalah apalagi dengan perbincangan yang tidak benar. Sehingga obrolan sesuai fakta seperti menceritakan kisah drama Korea kembali kepada orang lain akan lebih baik daripada berbicara bohong. Menonton drama korea hanya untuk memenuhi kebutuhan akan kebahagiaan dan kedamaian bagi penonton. Drama korea hanya sarana untuk membuat mahasiswa lebih merasa senang dan bahagia, serta memberikan banyak pengetahuan, pengalaman dan pelajaran-pelajaran yang berharga hanya dengan menontonnya.

Dalam hal ini peneliti menyimpulkan bahwa sebagian besar responden menggunakan media sebagai hiburan. Hal ini sesuai dengan fungsi komunikasi massa yakni hiburan. Dimana fungsi hiburan pada media massa bertujuan untuk mengurangi ketegangan pikiran khalayak karena dapat membuat pikiran segar kembali. ${ }^{21}$ Peneliti dapat mengambil kesimpulan, bahwa audiens memiliki kebutuhan dan tujuan sendiri dalam mengkonsumsi media dan bahwa terjadi kesenjangan antara motif dan

\footnotetext{
20 Qur'an Kemenag.

21 Chontina Siahaan, "Peran Media Televisi Dalam Pembentukan Realitas", Online Jurnal Universitas Kristen Indonesia, 5.23 (2018), hal. 9-10.
}

Vol. 3, No. 1, Juni 2020, pp 1-16 
kepuasan karena kepuasan yang diperoleh lebih besar daripada kepuasan yang diinginkan, sehingga penonton dapat merasa puas setelah menonton tayangan drama Korea. Hal ini membuat media harus lebih kreatif lagi dalam membuat karya film untuk bersaing dengan media massa lainnya.

\section{SIMPULAN}

Berdasarkan hasil penelitian dan analisis yang dilakukan mengenai Uses and Gratification mahasiswa Komunikasi dan Penyiaran Islam Universitas Islam Al-Ihya Kuningan terhadap drama Korea, maka dapat ditarik kesimpulan sebagai berikut :

1. Gratification Sought (Motif) mahasiswa Komunikasi dan Penyiaran Islam Universitas Islam Al-Ihya Kuningan bahwa penonton memiliki kebutuhan "saya ingin/dapat hiburan" atau tujuan sendiri dalam menggunakan media, hal ini berkaitan dengan beberapa karakter penonton itu sendiri. Hal ini sesuai dengan fungsi komunikasi massa yaitu hiburan. Dimana dengan hiburan dapat mengurangi ketegangan pikiran dan membuat pikiran segar kembali.

2. Gratification Obtained (Kepuasan) mahasiswa Komunikasi dan Penyiaran Islam Universitas Islam Al-Ihya Kuningan bahwa kepuasan yang diperoleh lebih besar daripada kepuasan yang diinginkan, sehingga penonton dapat merasa puas setelah menonton tayangan drama Korea. Hal ini membuat media harus lebih kreatif lagi dalam membuat karya film untuk bersaing dengan media massa lainnya.

\section{DAFTAR PUSTAKA}

Burkhardt, H, Recognizing Outstanding Ph, G Vogiatzis, C Hernández, Lutz Priese, Matthew Harker, and others, "Representasi Penyandang Disabilitas Dalam Film (Analisis Semiotika Barthes Dalam Film Serial Animasi "Nussa Dan Rara")", Society, (2019) (https://doi.org/10.1017/CBO9781107415324.004).

Handi, and Oktavianus, "Praktek Eksorsis Di Dalam Film Conjuring", E-Komunikasi, 3.2 (2015).

Hidayat, Muhammad Taufiq, "Computers in Human Behavior", UPT Perpustakaan ISI Yogyakarta, (2019), 9-57 (https://doi.org/10.1016/j.chb.2016.05.008).

Indonesia, Kedutaan Besar Republik Korea untuk Republik, "Hallyu : Gelombang Korea (Korea Wave)" (http://overseas.mofa.go.kr/id-id/wpge/m_2741/contents.do) [accessed 5 April 2020]

Indotesis.com, "Pengertian, Jenis Dan Unsur Drama"

(https://medium.com/@indotesis/pengertian-jenis-dan-unsur-drama-

1d69c088bcab) [accessed 5 April 2020]

Kriyantono, Rachmat, "Teknik Praktis Riset Komunikasi, Google Books", Kencana

Prenada Media Group, (2006)

(https://books.google.co.id/books?id=gl9ADwAAQBAJ\&pg=PA215\&lpg=PA215\&d

$\mathrm{q}=$ Gratification+Obtained+adalah+sejumlah+kepuasan+nyata+yang+diperoleh+in

Vol. 3, No. 1, Juni 2020, pp 1-16 
dividu\&source =bl\&ots=b_hjAuy82d\&sig=ACfU3U0qYLBaWyNh9FKwytG0zgxGNX zuBg\&hl=id\&sa=X\&ved=2ahUKEwiY_dn7vuToAhVZfSsKHU) [accessed 5 April 2020]

Moleong, Lexy J., “Metodologi Penelitian Kualitatif (Edisi Revisi)”, in PT. Remaja Rosda Karya, (2017).

Nompo, Ismed, “Uses and Gratification Theory”, (2016)

(https://www.kompasiana.com/ismednompo/58154bb5579773b5621e253b/uses-

and-gratification-theory?page=all).

Paluseri, "Kondensasi Dalam Analisis Data Penelitian Kualitatif", (2019)

(https://kacamatapustaka.wordpress.com/2019/11/08/kondensasi-dalam-analisisdata-penelitian-kualitatif-2/).

Puspita, Rintan, and Pangerang, "10 Drama Korea Terbaru Tayang Maret 2020, Yang Mana Paling Dinantikan?”, (2020)

(https://www.kompas.com/hype/read/2020/02/28/154714766/10-drama-koreaterbaru-tayang-maret-2020-yang-mana-paling-dinantikan?page=all)

Qur'an Kemenag, “Qur'an Kemenag”, Lajnah Pentashihan Mushaf Al-Qur”an, (2020).

Sapari, Yusuf, "Komunikasi Dalam Perspektif Teori Pertukaran", Jurnal Signal, 6.1 (2018), (https://doi.org/10.33603/signal.v6i1.950).

Sari, Deshinta Firstiiana, "Motif Menonton Drama Korea Di Televisi Oleh Remaja Surabaya", Commonline Departement Komunikasi, 4.1 (2015), (http://journal.unair.ac.id/download-fullpapers-comme465029b70full.pdf.)

Sari, Yunita Wulan, "Dampak Tayangan Drama Korea "Fashion King" Di Indosiar Pada Perilaku Konsumtif Remaja Putri Di Desa Karya Jaya", 2.2 (2014), (https://www.printfriendly.com/p/g/L4Z4Ht) [accessed 5 April 2020]

Siahaan, Oleh Chontina, "Peran Media Televisi Dalam Pembentukan Realitas", Online Jurnal Universitas Kristen Indonesia, 5.23 (2018).

Suyitno, "Penelitian Kualitatif", Journal Equilibrium, 5 No. 9.c (2009), (yusuf.staff.ub.ac.id/files/2012/11/Jurnal-Penelitian-Kualitatif.pdf)

Utomo, Dea Anggraeni, "Motif Pengguna Jejaring Sosial Google + Di Indonesia", EKomunikasi, 1.2 (2013).

Widoawati, Dewi, "Efek Media Massa Terhadap Khalayak", Jurnal Adzikra, 3.1 (2012), 75-98 (https://doi.org/10.1017/CBO9781107415324.004).

Wikipedia, "Teori Penggunaan Dan Pemenuhan Kepuasan", (2019)

(https://id.wikipedia.org/wiki/Teori_penggunaan_dan_pemenuhan_kepuasa) 